\title{
Comparative study of long-term water uptake of Norway spruce and Douglas-fir in Moravian upland
}

\author{
Nadezhda Nadezhdina*, Josef Urban, Jan Čermák, Valeriy Nadezhdin, Petr Kantor \\ Mendel University of Agriculture and Forestry, Faculty of Forestry and Wood Technology, Zemědělská 3, 61300 Brno, Czech Republic. \\ ${ }^{*}$ Corresponding author. Tel.: +42 54513 4181. E-mail: nadezdan@mendelu.cz
}

\begin{abstract}
Long-term water uptake of Douglas-fir and Norway spruce trees, growing in condition of Moravian upland, was studied with aim of comparing sap flow in small roots with flow in stems. Sap flow was measured by the heat field deformation method using multi-point sensors for stems and single-point sensors for roots. Differences between species were found in relationships between sap flow in tree stems and water uptake by roots, suggesting that Douglas-fir is able to take water from deeper soil more efficiently than spruce. This allows Douglas-fir to transpire more water especially during drought and grow faster than spruce. These biological features should be taken into account for future forest species compositions because they may have impact on both, forestry and hydrology.
\end{abstract}

Keywords: Sap flow; Shallow roots; Deep roots; Heat field deformation; Soil water potential.

\section{INTRODUCTION}

Main physiological and ecological properties of Norway spruce as well as Douglas-fir (Pseudotsuga menziesii) are generally known (Kantor, 2008; Savill, 1992; Úradníček et al., 2009). Norway spruce (Picea abies L., Karst.) is the most important commercial forest tree species in central Europe and therefore it was planted for centuries over the whole central and northern parts of Europe. This was done in suitable as well as unsuitable sites for this species, whose environmental requirements were often neglected in the past (Mäkinen et al., 2001; Nožička, 1957). Spruce is originally a high mountain species in central Europe, preferring altitudes up to about $1500 \mathrm{~m}$ or lowland tree in northern Europe. These are regions with higher precipitation (annually over $750 \mathrm{~mm}$ with no or low precipitation deficits) and air humidity. It also grows well in deep canyons. Norway spruce is adapted to cold winters. It is not much demanding on soil fertility, but does not grow well in calcareous regions. It suffers by higher temperatures and especially drought more frequently occurring in lower altitudes, warmer southern slopes, etc. This is often associated with its frequently occurring shallow root systems, which cannot easily reach bigger water sources in deeper soil layers. Shallow root systems make it also more vulnerable to wind throw. Unfavourable environmental, especially water supply conditions for this species lead to lowering its growth, loosing defending capabilities (which makes easier bark-beetle and fungi attack) and increasing its mortality. Such processes are evidently becoming more pronounced during global climatic changes.

Douglas-fir is known to be able to overcome many difficulties accompanying global warming. It grows better on some sites and is less vulnerable to the drought than Norway spruce (Bartoš and Kacálek, 2011; Kantor, 2008; Keyes and Grier, 1981; Peric et al., 2006; Šika and Vinš, 1980). Douglas-fir grows well in the lower rainfall areas if they are not much exposed. It is usually regarded as a species for middle valley slopes and bottoms of at least moderate fertility. It can develop good root systems on deep, well-drained soils. Clayey soils are acceptable if on slopes and the tree grows well on sandy soils; similarly like spruce is unsuitable to calcareous soils. Urban et al. (2012) found, that Douglas-fir is less sensitive than spruce to the unfavourable weather and soil nutrient conditions. It can withstand higher temperatures than spruce, but does not grow well in higher altitudes, where spruce dominates. It belongs to the group of the tallest tree species in frequently occurring volcanic soil in western parts of North America (Domec et al., 2008; Woodruff et al., 2007), where its relatively large water stem storage can help to satisfy higher transpiration demands (Čermák et al., 2007; Phillips et al., 2003). Douglas-fir can develop root systems much deeper than Norway spruce and numerous studies conducted in the USA indicate, that it can take water from deep soil horizons (Brooks et al., 2006; Meinzer et al., 2007). Deeper root system makes it also more resistant to wind throw.

When considering the present and possible future climatic changes, which seem not positive for spruce, we have to think also about other alternative species composition of new forests, where plant water relations, drought stress tolerance, water redistribution between soil and roots, etc. could play a decisive role on tree survival, production in terms of timber exploration, but also on important features associated with hydrology. It is well known that vegetation has strong impact on hydrology. The biological effect of the cloud forest on the water storage in the root zone was recently reported by Caballero et al. (2013). Trees can influence the hydrophysical parameters and water flow in a soil due to changes of soil water repellency (Lichner et al., 2013). A new forest composition may have impact on soil moisture status through transpiration and water uptake. For example, if roots of Douglas-fir are able to tap into deeper soilwater reservoirs, the latter can be effectively moved into the atmosphere through higher transpiration of Douglas-fir during drought. The aim of presented study was to compare long-term tree transpiration with water uptake by roots of both species, growing at the same site under similar climatic and edaphic conditions. 


\section{MATERIALS AND METHODS}

Site description and experimental design

The research plot Olomucany $(2220 \mathrm{~m} 2)$ was situated at forest stand 130 B 10 of the Training Forest Enterprise of the Mendel University of Agriculture and Forestry in Brno (latitude $49019^{\prime} 25^{\prime}$ 'N , longitude $16040^{\prime} 11^{\text {' }} \mathrm{E}$, altitude 460 $\mathrm{m})$. The mean annual precipitation amounted to $634 \mathrm{~mm}$ and mean air temperature $7.4^{\circ} \mathrm{C}$ (Vyskot, 1975). The soil type was described as cambisol mesothropic. The parent rock background was mostly amphiboly-biotitic granodiorite and biotitic acid granodiorite. Subsoil was composed mostly of Pleistocene sediments, loess and loess loam. Soils had middle level of important mineral elements.

Mixed forest (97 years old) was classified as the type $3 \mathrm{H}$ - Querceto-Fagetum illimerosum mesotrophicum according to the Czech forest type classification (Plíva, 1991). Sap flow in 6 spruce and 6 Douglas-fir trees on this plot was measured to evaluate transpiration on stand level (aim of another paper). The same sample trees were also measured by dendrometers and their growth was compared during several years. Two representing sample trees (one for each species) from those 12 measured were additionally equipped for sap flow measurements in small roots (three per each species) to compare water uptake. The xylem radii of both sample trees were rather similar: $18.9 \mathrm{~cm}$ and 19.6 $\mathrm{cm}$ respectively for spruce and Douglas-fir. Height of both trees was about $34 \mathrm{~m}$ and they represented part of the middle canopy layer. Sapwood conducting area (SWCA) of both trees was determined as area limited by tree xylem radius and radius of heartwood. Depth of sapwood (difference between tree xylem radius and heartwood) was evaluated by radial sap flow pattern as a border between sapwood and heartwood where sap flow approached zero.

\section{Measurements of meteorological data}

Meteorological data were measured by a Minikin thermohygrometer with radiation shelter and global radiation by a Minikin RT in an open space $150 \mathrm{~m}$ from the research plot. Data were measured every minute and stored as means over 10 minutes (all manufactured by EMS Brno, Czech Republic). Soil water potential (SWP) was measured at three depths $(10,30$ and $60 \mathrm{~cm}$ ) with three replications at each depth using calibrated gypsum blocks (Delmhorst Inc., USA; datalogger SP3, EMS Brno, Czech Republic) and stored every hour. Data for depths of 10 and $30 \mathrm{~cm}$ were averaged and analysed as shallow depth of $20 \mathrm{~cm}$

\section{Sap flow measurements}

Sap flow in roots and stem was measured during two years (2007 and 2008) using the heat field deformation method, HFD, where deformation of the heat field around a linear heater in a certain tangential section of the stem or root was taken as a measure of sap flow and calculated first as sap flow per section (Čermák et al., 2004; Nadezhdina et al., 1998). For stems sap flow per section was further converted to sap flow density and scaled up to tree level (Nadezhdina et al., 2002). For roots sap flow per section was not converted further to total root sap flow because we were interested only on qualitative seasonal changes of sap flow dynamics in roots.

Two modifications of sensors were used for sap flow investigations: the multi-point sensors (long) for the determination of the pattern of flow along xylem radius in tree stems and the single-point sensors (short) for measurements of flow in small roots. The single-point sensor contained one thermocouple, at 5 $\mathrm{mm}$ from its head. The multi-point sensor contained 5 thermocouples, $16 \mathrm{~mm}$ apart. Data were recorded in 10 minutes intervals by Unilog dataloggers Midi-12 (EMS Brno, Czech Republic).

Sap flow in tree stems was first measured by multi-point sensors from two opposite sides in order to cover both radial and circumferential flow variations. Radial profiles of sap flow were then averaged and correction factors were determined for each radial depth in order to up-scale sap flow to tree level using long-term one-side radial sap flow measurements. Three roots with diameter from 3 to $6 \mathrm{~cm}$ were carefully opened around each tree at a distance of about $1 \mathrm{~m}$ from a tree stem (Fig. 1). Spruce roots were found already at depth of $3 \mathrm{~cm}$ from soil surface, whereas Douglas-fir roots were deeper - at soil depth from 15 to $30 \mathrm{~cm}$ (there were no roots found at shallower depth). Single-point HFD sensors were installed in the chosen roots which were then covered by soil again after the sensor insulation.

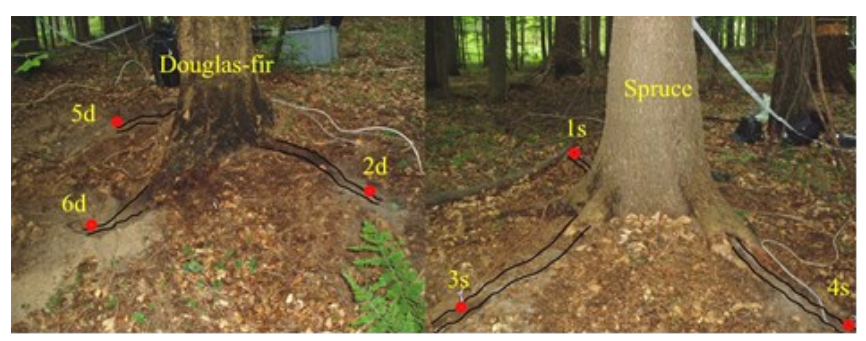

Fig. 1. Scheme of sensor installation on roots of spruce (right) and Douglas-fir (left) trees.

\section{Measurements of diameter increment}

Stem increment was measured on the same trees that were selected for sap flow measurements using vernier band dendrometers (EMS Brno, Czech Republic) with a resolution 0.1 $\mathrm{mm}$. Readings were taken weekly from 15.4.2008 to 15.10.2008. Automatic data-logging band dendrometers (DRL26, EMS Brno, Czech Republic) were installed additionally on two Douglas-firs and two Norway spruces in 2011. Breast height diameters $(\mathrm{DBH})$ of the investigated trees were 51 and $66 \mathrm{~cm}$ for Douglas-fir and 44 and $51 \mathrm{~cm}$ in Norway spruce. Diurnal diameter fluctuations were recorded every 10 minutes and average dynamics of both trees for each species was compared. For better comparison data for each species were normalized by average tree diameter for the beginning of the analyzed period.

\section{RESULTS AND DISCUSSION}

Meteorological conditions differed between two studied years, especially by periods of soil drying (Fig. 2). Soil moisture started to decrease one month later in 2008, but drought lasted twice longer than in 2007 especially in deeper soil. Superficial soil layers were wetter in year 2008 due to small but often rains. Differences in meteo and especially in edaphic conditions within two years of observations were reflected in transpiration of both trees (Fig. 3). Although relationship between sap flow dynamics was very high in $2007\left(\mathrm{r}^{2}\right.$ equal to 0.87$)$ sap fluxes in spruce were twice lower than in Douglas-fir. The difference in fluxes was accounted in relationship between tree sap flow in both trees by different scale of $\mathrm{X}$ - and $\mathrm{Y}$-axes. This difference cannot be explained by a smaller circumference of spruce stem 
comparing to Douglas-fir. Under the same sapwood depth $(5.5$ $\mathrm{cm})$ SWCA of Douglas-fir $\left(582 \mathrm{~cm}^{2}\right)$ was only $4 \%$ larger than SWCA of spruce $\left(558 \mathrm{~cm}^{2}\right)$. Progressive soil drying in deeper layers during the next year 2008 caused decrease of fluxes magnitude in both trees, but with more than twice higher extent for spruce: slope of relationship was changed from 0.43 to 0.18 , $\mathrm{r}^{2}$ dropped till 0.71 (Fig. 3, right panel). Substantially lower transpiration rate of spruce canopy compare to beech or to larch canopy transpiration were also recorded in mixed forests in nearby Slovakia (Střelcová et al., 2006, 2009).
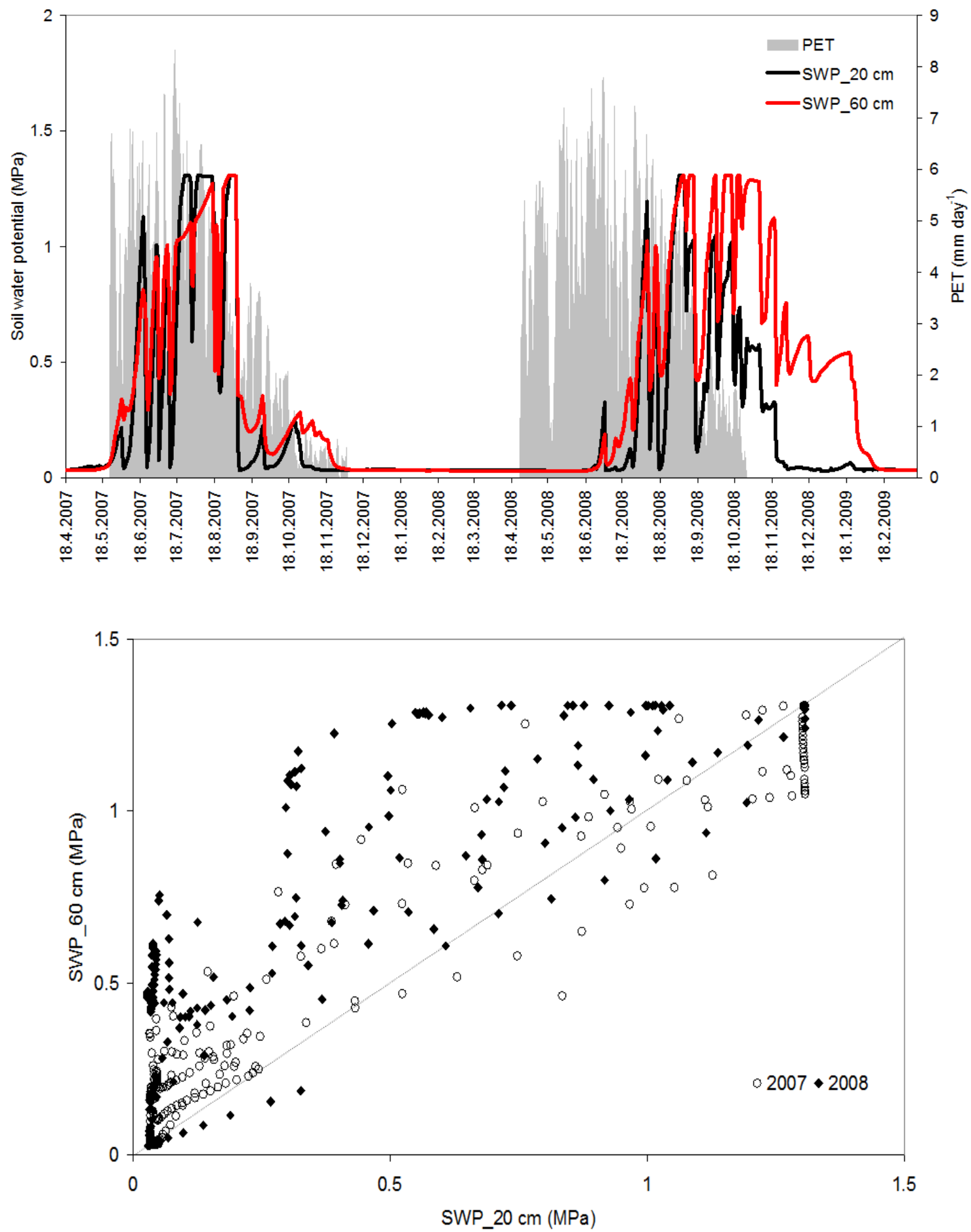

Fig. 2. Upper panel: Seasonal dynamics of potential evapotranspiration PET and soil water potentials at depth of 20 and $60 \mathrm{~cm}$ measured at site Olomucany.

Lower panel: Relationship between soil water potentials at depth of 20 and $60 \mathrm{~cm}$ for two years of observation indicating prevailing of dryer conditions in deeper soil layer for year 2008.

Values of soil water potentials are shown with the opposite mark at both panels. 
Long-term observation also demonstrated differences in night sap flow behaviour (see Fig. 3). Although both trees had rather often high values of night flow its magnitude was more than twice higher for Douglas-fir than for spruce. Night flow was coming to zero only at nights with zero VPD or during drizzly weather. Reverse night flows were often recorded in stem of spruce tree during such nights but very seldom in Douglas-fir where they were sometimes recorded only in late autumn. Reverse night flow was more often recorded in spruce stem in 2008 whereas higher values of night flow were recorded in Douglas-fir. This may indicate higher ability of spruce to utilize foliar uptake (Burgess and Dawson, 2004; Nadezhdina et al., 2010) during night with high humidity (there were more nights with low VPD in 2008 compare to 2007) and by this way partially compensate lower ability to deep water uptake than Douglas-fir. Further research is needed to confirm this hypothesis.
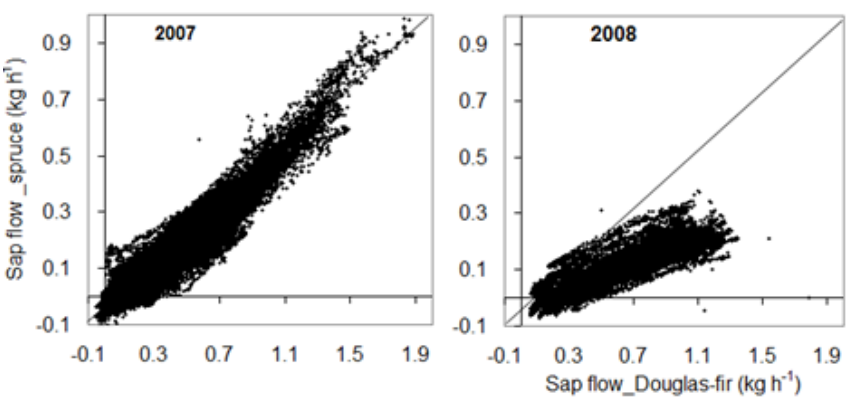

Fig. 3. Relationship between hourly sap fluxes in Douglas-fir and spruce trees during two contrasting years.
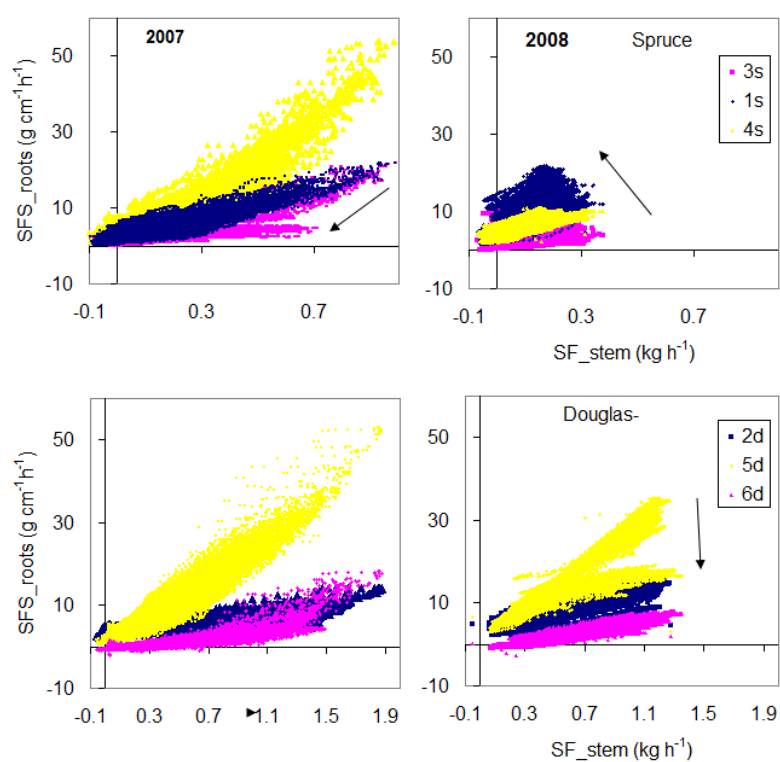

Fig. 4. Relationships between sap flow in stem and roots of spruce (upper panels) and Douglas-fir (lower panels) trees for two contrasting years. Sap flow in three roots of each tree is marked by different colors. Arrows indicate direction of changes in relationship with drought coming.

In order to understand the reason for such big differences in transpiration of both species, relationship between their stem flow and water uptake by roots was compared (Fig. 4). It was found out that sap flow in stem of both species was proportional to water uptake of two observed roots ( $1 \mathrm{~s}$ and $4 \mathrm{~s}$ for spruce and $2 \mathrm{~d}$ and $6 \mathrm{~d}$ for Douglas-fir) during the whole observed period. Such roots could be classified as deep roots (David et al., 2013).
However, slope of relationship decreased for root $3 \mathrm{~s}$ (spruce) and 5d (Douglas-fir) with coming drought and with higher extent for spruce root. This could be taken as evidence that both those roots were situated in shallower soil layers. Spruce roots were spread from the stem at a very shallow soil depth (as it was already found out during sensors installation) that is why their response to soil drying (decrease of slope of relationship between transpiration and water uptake) was more substantial than in Douglas-fir in 2007. Next year 2008 brought more progressive drying also in deeper soil layers (see Fig. 2) and this was reflected in root water uptake of Douglas-fir (see root 5d) similarly as for spruce in 2007 (see root 3s) but without drastical decrease of transpiration which was evidently supported by other more deep non-measured roots. Water uptake was smaller in spruce root $4 \mathrm{~s}$ in 2008 , but it was supported at the same level in root $1 \mathrm{~s}$. This may suggest that root $4 \mathrm{~s}$ was situated deeper than root $1 \mathrm{~s}$ which was watered by often small rains. Such analyses of seasonal sap flow behaviour in stem and roots together with soil water potential in different soil layers allow distinguish vertical root positioning without root opening.

Two from three studied roots which were classified as shallow (3s and 5d) and deep (4s and 2d) for both species (see paragraph above) were chosen for further analyses and relationship between them was compared for both observed years (Fig. 5). We can see similar tendency for roots of both trees with more pronounced decrease of water uptake by deep root in spruce than in Douglas-fir. It could be taken as confirmation that "deep" root of Douglas-fir should be substantially deeper than "deep" root of spruce.

Differences in transpiration between both species were reflected in their seasonal growth (Fig. 6) which was three times higher in Douglas-fir. Additional more precise measurements of stem circumferential increment in Douglas-fir and spruce trees measured at the same forest after summer drought in Autumn of 2011 indicate that in accordance of almost three times bigger shrinkage of spruce stem the later should more suffer from drought than Douglas-fir (Fig. 7). Evidently under the same growing conditions Douglas-fir can better replenish stem reserves during nights thanks to presence of deeper roots.
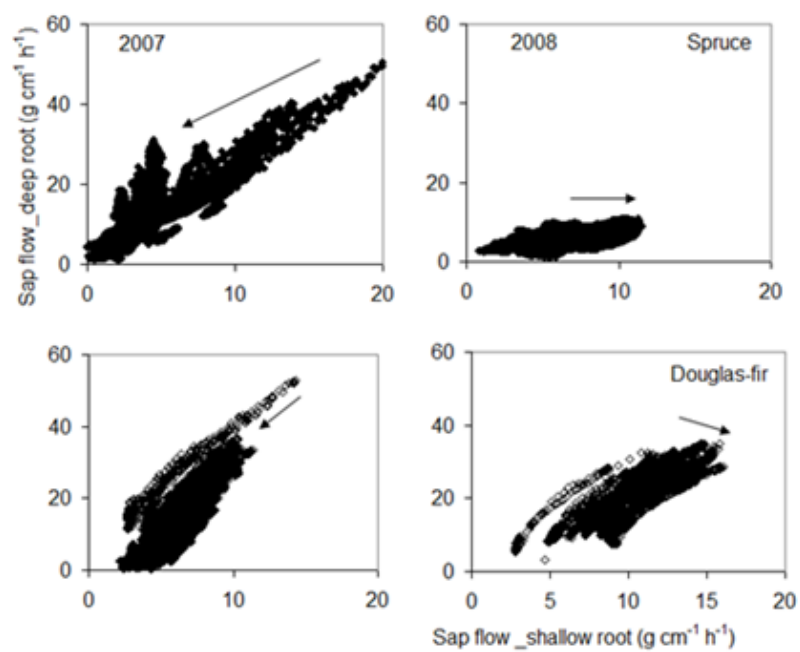

Fig. 5. Relationship between seasonal sap flow in shallow (3s) versus deep (4s) roots of spruce (upper panels) and in shallow (5d) versus deep (2d) roots of Douglas-fir (lower panels) during two contrasting years (see also Figs. 1 and 7). Arrows indicate direction of changes in relationships from June to September of each year. 


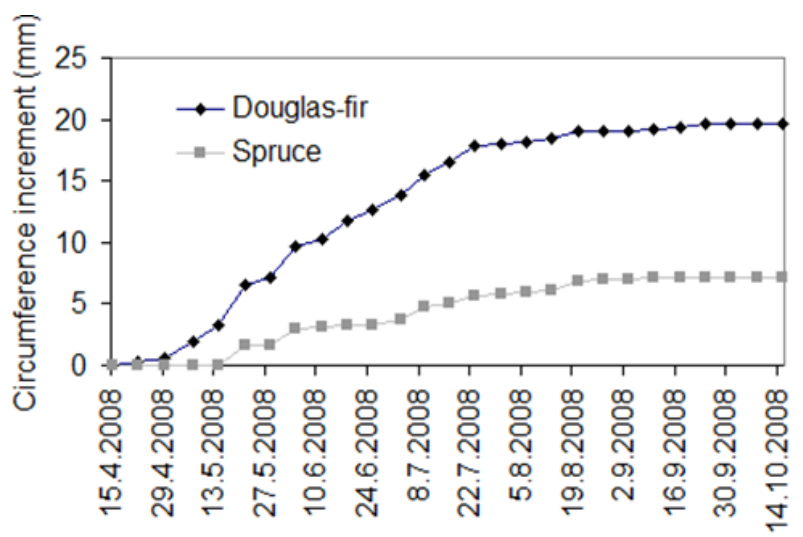

Fig. 6. Seasonal dynamics (2008) of stem circumferences increment for Douglas-fir and spruce trees.

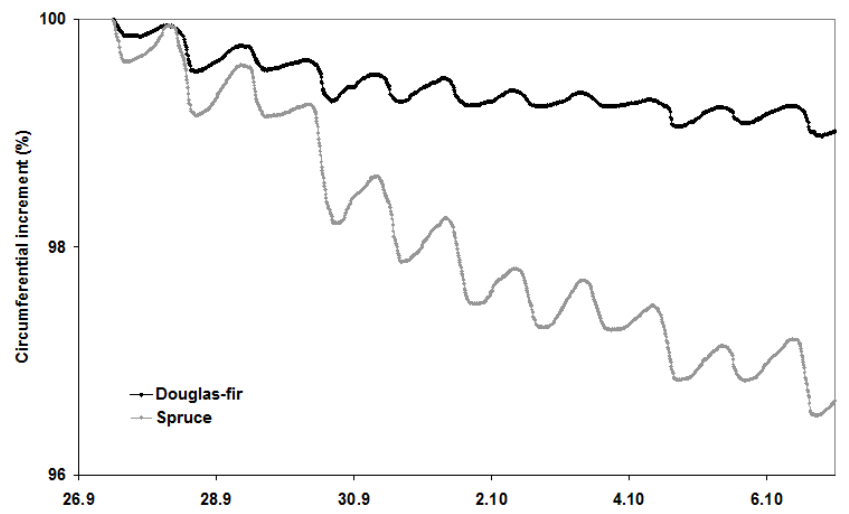

Fig. 7. Diurnal circumferential stem variation of Douglas-fir (black) and spruce (grey) trees recorded in autumn of 2011 after summer drought. For better comparison both curves were normalized to the initial value.

\section{CONCLUSIONS}

Comparative study of transpiration and water uptake by roots of Douglas-fir and Norway spruce growing under the same conditions of the Moravian Upland demonstrated that Douglasfir was less sensitive to the soil water deficit due to ability to take it more efficiently than Norway spruce from deeper soil horizons. This allowed Douglas-fir transpire more water than spruce during drought. These different biological features of two species lead to hydrological changes in the observed forest: prolonged period with high evaporative demands in 2008 caused drying of deeper soil layers.

Acknowledgement. This research was supported by the projects NAZV QI 112A172 "Silvicultural approaches to use Douglasfir in mixed stands in the Czech Republic", OPVKCZ.1.07/2.3.00/20.0267 and IGA-LDF-73/2013.

\section{REFERENCES}

Bartoš, J., Kacálek, D., 2011. Wood production of young firstgeneration stands on former agricultural land. Reports of Forest Research, 56, 118-124.

Brooks, J.R., Meinzer, F.C., Warren, J.M., Domec, J.C., Coulombe, R., 2006. Hydraulic redistribution in a Douglas-fir forest: lessons from system manipulations. Plant Cell and Environment, 29, 138-150.

Burgess, S.S.O., Dawson, T.E., 2004. The contribution of fog to the water relations of Sequoia sempervirens (D. Don): foliar uptake and prevention of dehydration. Plant, Cell and Environment, 27, 1023-1034.

Caballero, L.A., Easton, Z.M., Richards, B.K., Steenhuis, T.S., 2013. Evaluating the bio-hydrological impact of a cloud forest in Central America using a semi-distributed water balance model. Journal of Hydrology and Hydromechanics, 61, 9-20.

David, T.S., Pinto, C.A., Nadezhdina, N., Kurz-Besson, C., Henriques, M.O., Quilhó, T., Čermák, J., Chaves, M.M., Pereira, J.S., David, J.S., 2013. Root functioning, tree water use and hydraulic redistribution in Quercus suber trees: A modeling approach based on root sap flow. Forest Ecology and Management, 307, 136-146.

Domec, J.C., Lachenbruch, B., Meinzer, F.C., Woodruff, D.R., Warren, J.M., McCulloh, K.A., 2008. Maximum height in a conifer is associated with conflicting requirements for xylem design. Proceedings of the National Academy of Science of the United States of America, 105, 33, 12069-12074.

Čermák, J., Kucera, J., Nadezhdina, N., 2004. Sap flow measurements with some thermodynamic methods, flow integration within trees and scaling up from sample trees to entire forest stands. Trees, 18, 529-546.

Čermák, J., Kucera, J., Bauerle, W.L., Phillips, N., Hinckley, T.M., 2007. Tree water storage and its diurnal dynamics related to sap flow and changes of trunk volume in old-growth Douglas-fir trees. Tree Physiology, 27, 181-198.

Kantor, P., 2008. Production potential of Douglas fir at mesotrophic sites of Krrtiny Training Forest Enterprise. Journal of Forest Science, 54, 321-332.

Keyes, M.R., Grier, C.C., 1981. Above-and below-ground net production in 40-year-old Douglas-fir stands on low and high productivity sites. Canadian Journal of Forest Research, 11, 599-605.

Lichner, L., Capuliak, J., Zhukova, N., Holko, L., Czachor, H., Kollar, J., 2013. Pines influence hydrophysical parameters and water flow in a sandy soil. Biologia, 68, 1104-1108.

Meinzer, F.C., Warren, J.M., Brooks, J. R., 2007. Speciesspecific partitioning of soil water resources in an old-growth Douglas-fir-western hemlock forest. Tree Physiology, 27, 871-880.

Mäkinen, H., Nöjd, P., Mielikäinen, K., 2001. Climatic signal in annual growth variation in damaged and healthy stands of Norway spruce [ Picea abies (L.) Karst.] in southern Finland. Trees, 15, 177-185.

Nadezhdina, N., Čermák, J., Nadezhdin, V., 1998. Heat field deformation method for sap flow measurements. In Measuring Sap Flow in Intact Plants. Eds. J. Čermák and N. Nadezhdina. Proc. 4th. Int. Workshop, Zidlochovice, Czech Republic, IUFRO Publications. Brno, Czech Republic, Publishing House of Mendel University, pp 72-92.

Nadezhdina, N., Čermák, J., Ceulemans, R., 2002. Radial patterns of sap flow in woody stems of dominant and understory species: scaling errors associated with positioning of sensors. Tree Physiology, 22, 907-918.

Nadezhdina, N., Čermák, J., Gasparek, J., Nadezhdin, V., Prax, A., 2006.Vertical and horizontal water redistribution wit,hin Norway spruce (Picea abies) roots in the Moravian Upland. Tree Physiology, 26, 1277-1288.

Nadezhdina, N., David, T.S., David, J.S., Ferreira, I., Dohnal, M., Tesar, M., Gartner, K., Leitgeb, E., Nadezhdin, V., Čermák, J., Jimenez, M.S., Morales, D., 2010. Trees never rest: the multiple facets of hydraulic redistribution. Ecohydrology, 3, 431-444.

Nožička, J., 1957. History of our forests (in Czech). SZN Prague, Prague. 
Plíva, J., 1991. Functionally integrated forest management. 1. Forest site condition classification (in Czech). Institute of Forest Management (UHUL), Brandýs nad Labem, Czech Republic.

Peric, S., Seletkovic, I., Medak, J., Pilaš, I., Topic, V., 2006. Research of thriving of six coniferous species in ecologically characteristic regions of Croatia. Rad. Sumar. inst. Izvanredno izdanje, 9, 99-108.

Phillips, N.G., Ryan, M.G., Bond, B.J., Dowell, N.G.M.C., Hinckley, T.M., Čermák, J., 2003. Reliance on stored water increases with tree size in three species in the Pacific Northwest. Tree Physiology, 23, 237-245.

Savill P.S., 1992. The silviculture of trees used in British forestry. CAB International, Wallingford, UK, 144p.

Střelcová, K., Mind'áš, J., Škvarenina, J., 2006. Influence of tree transpiration on mass water balance of mixed mountain forests of the West Carpathians. Biologia, 61, 305-311.

Střelcová, K., Kučera, J., Fleischer, P., Giorgi, S., Gomoryová, E., Škvarenina, J., Ditmarová, L., 2009. Canopy transpiration of mountain mixed forest as a function of environmental conditions in boundary layer. Biologia, 64, 507-511.

Úradníček, L., Maděra, P.; Tichá, S., Koblížek, J., 2009. Woody species of the Czech Republic (in Czech). Lesnická práce, Praha, 368p.

Urban, J., Holušová, K., Menšík, L., Čermák, J., Kantor, P. 2013. Tree allometry and stem growth of Douglas fir and Norway spruce on nutrient-poor and nutrient-rich site. Trees, $27,97-110$.

Woodruff, D.R., David, R., McCulloh, K.A., Katherine, A., Warren, J.M., Jeffrey, M., Meinzer, F.C., Frederick, C., Lachenbruch, B., 2007. Impacts of tree height on leaf hydraulic architecture and stomatal control in Douglas-fir. Plant Cell and Environment, 30, 559-569.

Received 24 April 2013 Accepted 13 August 2013 